Subscriber access provided by WESTERN KENTUCKY UNIV

\title{
Fossil Fuels
}

\section{Acid Leaching of Rare Earth Elements from Coal and Coal Ash: Implications for Using Fluidized Bed Combustion to Assist in the Recovery of Critical Materials}

Rick Honaker, Wencai Zhang, and Joshua Werner

Energy Fuels, Just Accepted Manuscript • DOI: 10.1021/acs.energyfuels.9b00295 • Publication Date (Web): 30 May 2019

Downloaded from http://pubs.acs.org on June 4, 2019

\section{Just Accepted}

"Just Accepted" manuscripts have been peer-reviewed and accepted for publication. They are posted online prior to technical editing, formatting for publication and author proofing. The American Chemical Society provides "Just Accepted" as a service to the research community to expedite the dissemination of scientific material as soon as possible after acceptance. "Just Accepted" manuscripts appear in full in PDF format accompanied by an HTML abstract. "Just Accepted" manuscripts have been fully peer reviewed, but should not be considered the official version of record. They are citable by the Digital Object Identifier (DOI尺). "Just Accepted" is an optional service offered to authors. Therefore, the "Just Accepted" Web site may not include all articles that will be published in the journal. After a manuscript is technically edited and formatted, it will be removed from the "Just Accepted" Web site and published as an ASAP article. Note that technical editing may introduce minor changes to the manuscript text and/or graphics which could affect content, and all legal disclaimers and ethical guidelines that apply to the journal pertain. ACS cannot be held responsible for errors or consequences arising from the use of information contained in these "Just Accepted" manuscripts. 


\title{
Acid Leaching of Rare Earth Elements from Coal and Coal Ash: Implications for Using Fluidized Bed Combustion to Assist in the Recovery of Critical Materials
}

\author{
R. Q. Honaker*, W. Zhang and J. Werner \\ University of Kentucky, Department of Mining Engineering, Lexington, KY 40506
}

\begin{abstract}
High temperature pretreatment of coal-based mineral matter in an oxidizing environment significantly enhances the leaching characteristics of rare earth elements (REEs). A research study has found that the temperatures used in fluidized-bed combustion (FBC) of coal to produce electricity are near optimum for pre-treating the associated mineral matter prior to leaching to maximize the recovery of critical materials. Tests were performed on representative samples collected from preparation plants treating West Kentucky No. 13, Illinois No. 6, and Fire Clay coal seam sources as well as fly ash and bed ash samples from two FBC power plants. Acid leaching tests using $1.2 \mathrm{M} \mathrm{HCl}$ at $75^{\circ} \mathrm{C}$ were performed on both the coal and the $\mathrm{FBC}$ ash samples. Prior to leaching, the coal samples were pretreated at temperatures of $600^{\circ} \mathrm{C}, 750^{\circ} \mathrm{C}$, and $900^{\circ} \mathrm{C}$ in an oxidizing environment to study the effect on leaching characteristics. The results showed that pretreatment at $600^{\circ} \mathrm{C}$ for 2 hours resulted in a significant increase in REE recovery from a range of $20-40 \%$ to about $80 \%$ for all coal sources. The leaching kinetics are characterized by a quick release of rare earth elements within the first few minutes of the process. For the West Kentucky No. 13 coal source, about $75 \%$ of REEs were leached in the first 15 min from the 1.4-1.8 specific gravity (SG) fraction that was calcined at $600^{\circ} \mathrm{C}$. Additionally, the leaching kinetics of the major contaminant, i.e., Fe, were much lower than the REEs, which significantly benefits the efficiency of leaching and the downstream upgrading processes. REE leaching characteristics of the FBC ash samples were similar to that of the calcined coals. Mineralogy characterization showed that the degree of crystallinity for both the calcined coal and FBC samples were similar to the original associated mineral matter, which provided evidence for the advantage of using the FBC byproducts as REE feedstocks over pulverized coal boilers that utilize temperatures greater than $1200^{\circ} \mathrm{C}$. These findings were used to develop a conceptual flowsheet that incorporates FBC technology and its typical combustion environment to enhance the feasibility of recovering critical materials from coal-based sources.
\end{abstract}




\section{Introduction}

It is increasingly important to recover critical materials from alternative and secondary resources due to their important role in critical areas (e.g., clean energy and advanced electronic technologies) and an uneven production distribution worldwide. ${ }^{1-3}$ The findings from several attempts to recover rare earth elements (REEs) from coal related materials have been reported in a number of recent publications (e.g., coal, coal refuse, coal ash, and coal mine drainage). ${ }^{4-9}$

Four genetic types of REE accumulation in coal have been identified: terrigenous, tuffaceous, infiltrational, and hydrothermal types. ${ }^{10,11}$ REE accumulation in a coal deposit may have a polygenetic and multistage nature. ${ }^{10,12,13}$ For example, in the lower, middle and upper zones of the Wulantuga coal deposit, early syngenetic hydrothermal input, middle syngenetic terrigenous input (mainly detrital minerals), and late diagenetic hydrothermal input contributed to the accumulation of REEs, respectively. ${ }^{12}$ The Fire Clay coal seam is well-known for its relatively high REE contents, which is mainly due to the tonstein layer (tuffaceous input) existing in the seam. ${ }^{10,14,15}$ Leaching of the tonstein material (infiltrational input), detrital mineral input into the peat, and subtle hydrothermal fluid from the southeast side also caused the enrichment of REEs in the upper and lower benches of the coal seam. ${ }^{10}$

Fractionation of the REEs in coal seams occurred due to the different genetic types and chemical natures of REEs. The findings of several studies report that heavy REEs (Eu, Gd, Tb, Dy, $\mathrm{Ho}, \mathrm{Er}, \mathrm{Tm}, \mathrm{Yb}, \mathrm{Lu}$, and Y) are more likely enriched in low-ash content coals than high-ash coals (partings, roof, floor, etc.). 5,9,12,13,16-19 HREEs are selectively desorbed and/or leached relative to LREEs from clays, tonsteins, etc. ${ }^{20-22}$ Many natural solutions (e.g., alkaline terrestrial water, some high $\mathrm{pCO}_{2}$ weakly acid cold mineral water, and some hydrothermal solutions) are enriched in HREEs and may circulate in coal basins. ${ }^{12,16,22}$ The presence of humic substances (mainly humic acids) in coal during the coalification process provided a stronger complexation ability with HREEs than LREEs. ${ }^{23,24}$ All of these factors contributed to the high enrichment of HREEs in low-ash content fractions of coal sources. These fractions are typically recovered from coal upgrading plants and used for power generation and steel production.

REE recovery from both moderate-ash content coals (e.g., middlings) and high-ash refuse have been previously reported. ${ }^{19,25-28}$ However, a detailed study conducted on various particle size and density fractions of material collected from the process streams of 20 coal preparation plants revealed that the highest REE concentrations, particularly the highly-valued heavy REEs, exist in the mineral matter of the lowest density, low-ash fractions of high rank coal sources. ${ }^{29}$

For low-rank coals (e.g., lignite), satisfactory leaching recovery $(>80 \%)$ of the REEs has been obtained using mild leaching conditions such as $1 \mathrm{M} \mathrm{HCl} .{ }^{27}$ However, leaching of the clean coal and middling fractions of high-rank coals (e.g., bituminous) is more difficult likely due to the lack of exposure to the micro-dispersed mineral matter that are associated with the REEs. ${ }^{25,28}$ In this case, grinding is required to liberate the ash-forming material from the low-ash high-rank coals. As reported by Honaker et al. ${ }^{25}$, about $80 \%$ of the REEs were leached from a liberated, decarbonized Fire Clay middlings material using $1.2 \mathrm{M} \mathrm{H}_{2} \mathrm{SO}_{4}$. Limited successes were reported when leaching decarbonized West Kentucky No. 13 and Lower Kittaning middling sources. In addition, the grinding cost to liberate ash materials from some coal sources such as Fire Clay coal, is prohibitively high. ${ }^{30}$ 
When coal is used for power generation, the REEs are enriched in the ash byproducts (fly ash and bottom ash) due to the removal of the carbon and volatile matter. As such, several studies have been performed to recover REEs from coal ash material. ${ }^{4,31,32}$ However, combustion temperatures exceeding $1200^{\circ} \mathrm{C}$ are used in most conventional coal-fired power plants. ${ }^{33}$ At these high temperatures, significant mineralogical changes of the original mineral matter occurs. Instead of occurring as individual minerals, it has been reported that most REEs are homogeneously distributed in a glassy amorphous matrix. ${ }^{34-37}$ As such, strong acidic and/or basic solutions are required to dissolve the REEs from the fly ash material. ${ }^{4,37}$ In addition to the high costs of the lixiviants, the dissolution of the fly ash material needed to achieve a high REE recovery results in an excessive amount of contaminate ions in solution which hinders the ability to achieve high grade REE concentrates from downstream processes.

A recent study by Yang et al. ${ }^{28}$ found that, by using $1.2 \mathrm{M} \mathrm{H}_{2} \mathrm{SO}_{4}$, REE recovery from West Kentucky No. 13 decarbonized middlings was increased from $31 \%$ to $74 \%$ by calcination at $750^{\circ} \mathrm{C}$ for 2 hours. Significant increases in REE recovery from the Pocahontas No. 3 middlings and coarse refuse were also achieved using calcination..$^{38}$ As such, burning coals at lower temperatures (e.g., $750^{\circ} \mathrm{C}$ ) improves REE recovery which may be due to the decomposition of the rare earth minerals and/or the associated mineral matter such as clays. Unlike conventional boilers, fluidized bed combustion units use a combustion temperature that typically ranges from $750-900^{\circ} \mathrm{C}$ for power generation and thus may provide an opportunity to provide byproduct material enriched with heavy REEs and ideal for achieving relatively high REE recovery from leaching processes. ${ }^{39}$ To the authors' knowledge, there have been no previous recognition of the mutual benefit of FBC units for power production and critical material recover. FBC units are well-developed technology and embraces numerous advantages such as fuel flexibility, lower NOx emission, high combustion efficiency, etc. ${ }^{39,40}$ It is proposed that an added benefit is a combustion environment that is nearly ideal for calcination of a material enriched in REEs prior to leaching.

In this study, the beneficial use of the FBC combustion environment to assist in the recovery of REEs from low-ash coals was evaluated. A 1.4 specific gravity (SG) float and 1.4-1.8 SG fraction of West Kentucky No. 13, Illinois No. 6, and Fire Clay coals were calcined at different temperatures and residence times. Additionally, both fly ash and bed ash samples were collected from two power generation plants that use FBC boilers. Acid leaching tests were performed on both the original coal and calcined samples as well as the FBC ash samples. The REE leaching characteristics of the calcined samples were compared with the FBC ash byproducts. The findings of the study were used to develop a conceptual flowsheet utilizing FBC units for energy and enhanced REE concentrate production.

\section{Material and Methods}

2.1. Material. Representative feed samples of run-of-mine coal were collected from the feed belts of three coal preparation plants that processed coal originating from the West Kentucky No. 13, Fire Clay, and Illinois No. 6 coal seams, respectively. The samples were dry screened to obtain the plus $1 \mathrm{~cm}$ fractions which were then density fractionated using a magnetite-based dense media of 1.4 and 1.8 specific gravity (SG). The 1.4 SG float and 1.4-1.8 SG fractions were dried in open atmosphere and crushed to minus $0.18 \mathrm{~mm}$. The pulverized samples were used as feed materials for the experiments.

Fly ash and bed ash samples were collected from two power plants (FBC1 and $\mathrm{FBC} 2)$ that use fluidized bed combustion boilers. The FBC1 is typically provided fuel from Illinois No. 6 coal 
seam sources which is subjected to combustion temperatures around $790^{\circ} \mathrm{C}$. The $\mathrm{FBC} 2$ unit receives feedstocks from a number of coal waste areas within a $80 \mathrm{~km}$ radius that were generated from coals extracted from Upper, Middle and Lower Kittanning seams and Upper and Lower Freeport seams. The combustion temperature used in $\mathrm{FBC} 2$ is $870^{\circ} \mathrm{C}$. All of the coal sources in this study were high volatile, bituminous coals including the feedstocks to the FBC units.

2.2. Methods. The effects of high temperature treatment on REE leaching characteristics from the coal sources were investigated by calcination and acid leaching tests, which provided supporting evidence of the potential feasibility of utilizing FBC units to provide the pre-leach calcination while combusting coal for power generation. Calcination was performed using an oven manufactured by Thermo Fisher under different temperatures $\left(600,750\right.$ and $\left.900^{\circ} \mathrm{C}\right)$. The calcination temperatures were reached by elevating from $25^{\circ} \mathrm{C}$ at a rate of $10^{\circ} \mathrm{C} / \mathrm{min}$. Unless otherwise noted, the samples were calcined at the temperatures for $120 \mathrm{~min}$, after which, the system was cooled down automatically to $25^{\circ} \mathrm{C}$. To study the effects of the pretreatment time, the 1.4-1.8 SG coals were calcined at $600^{\circ} \mathrm{C}$ for different periods, i.e., 10,60 and $120 \mathrm{~min}$.

Acid leaching tests were conducted in a round bottom flask which was submersed in a water bath for temperature control. The flask was connected to a condenser to prevent the liquid loss due to evaporation. The leaching tests were performed under a uniform condition, i.e., $75^{\circ} \mathrm{C}, 1 \%$ solid concentration by weight, $1.2 \mathrm{M} \mathrm{HCl}$, and $500 \mathrm{rpm}$ magnetic stirring. A total volume of 1 liter was utilized for each test. Slurry samples of $15 \mathrm{~mL}$ were collected at 5, 15, 30, 45, 60, 90, 120, 180, 240 and $300 \mathrm{~min}$ from the beginning of the leaching process. Weights of the slurry samples were recorded. The slurry samples were filtered using a $0.45 \mu \mathrm{m}$ pore size filter-mate supplied by Environmental Express. Elemental concentrations in the filtrate were measured using ICP-OES. After 300 min of leaching reaction, the residual slurry was filtered using a $0.45 \mu \mathrm{m}$ pore size filter paper. The filter cakes were dried at $60^{\circ} \mathrm{C}$ and digested for ICP measurements. In an effort to assess the quality of the test data, elemental contents $\left(E_{f}, \mathrm{ppm}\right)$ in the feed solids were back calculated using the following equation:

$$
E_{f}=100 \times\left(C_{s} \times m_{s}+C_{l} \times V_{l}\right) \times m_{i} /\left(m_{i}-m_{m}\right) .
$$

where $C_{s}$ and $C_{l}$ represent the elemental concentrations (ppm) in the solid residual and final leachate; $m_{s}(\mathrm{~kg})$ weight of the leaching solid residual; $V_{l}$ (liter) volume of the residual leachate; $m_{i}(\mathrm{~kg})$ weight of the total leaching slurry; and $m_{m}(\mathrm{~kg})$ weight of all the representative samples collected during the leaching process. The difference between the back-calculated contents and the values measured directly using ICP was within $\pm 5 \%$, indicating minor experimental errors. Leaching recovery $\left(R_{i}, \%\right)$ was calculated using the following expression:

$$
R_{i}=100 \% \times C_{i} \times V /\left(E_{f} \times 0.01\right) .
$$

where $C_{i}(\mathrm{ppm})$ represents elemental concentrations in the filtrates collected during the leaching process, $V$ volume of the feed solution (1 liter), and $E_{f}$ (ppm) the back-calculated elemental contents in the feed solids. Leaching tests were run in triplicates and the standard deviation for the total REE recovery values was less than $1 \%$.

Digestion of the solid samples followed the ASTM D6357-11 standard ${ }^{41}$, which utilized hydrofluoric, nitric, and hydrochloric acids of trace metal basis at an elevated temperature. For each batch of digestion, a standard solid sample supplied by National Institute of Standards and Technology (NIST) of the U.S. Department of Commerce was digested together with the solid samples. REEs and the other key elemental concentrations were also measured for quality control 
purposes. The differences between the measured contents and the values provided by the NIST were $\pm 10 \%$. Proximate analyses of the samples were performed following the ASTM D5142 standard. X-ray diffraction (XRD) characterization was used for a mineralogy study using a BrukerAXS D8 DISCOVER diffractometer which was configured in a parallel beam geometry with Cu$\mathrm{K} \alpha$ radiation. XRD patterns were recorded over a $2 \theta$ range of $5^{\circ}-70^{\circ}$ with a step size of $0.02^{\circ}$. XRD patterns were analyzed using DIFFRAC, a commercial software developed by Bruker Corporation.

\section{Results and Discussion}

3.1 Sample Characterization. When reported on a dry ash basis, the Fire Clay coal sources contained significantly more total REEs (TREEs including lanthanide elements plus Y and Sc) than the West Kentucky No. 13 and Illinois No. 6 coals, especially for the 1.4 SG float fraction (2014 ppm versus 490 ppm and 393 ppm, respectively). The relatively high REE contents in the Fire Clay coal sources have been attributed to the tonstein layer that exists in the coal bed. ${ }^{10,14,15}$ The heavy REEs (HREEs including Eu, Gd, Tb, Dy, Ho, Er, Tm, Yb, Lu and Y) were enriched in the lower density fractions (1.4 SG float) for all the sources as indicated by the relatively high heavy to light REE (LREEs including La, Ce, Pr, Nd, Sm and Sc) content ratio (H/L) (Table 1). This agrees with previous studies and can be explained by the higher complexation ability of organic substances (mainly humic acids) with HREEs relative to LREEs. ${ }^{16,17,22}$ The FBC1 fly ash and bottom ash samples contained $232 \mathrm{ppm}$ and $96 \mathrm{ppm}$ of REEs, respectively, which was lower than the FBC2 samples (289 ppm and $298 \mathrm{ppm}$ ). The REE contents of all FBC samples were lower than the coal sources which is noteworthy since the FBC1 plant utilizes Illinois No. 6 coal sources as a fuel. The difference was likely due to the dilution effect of the lime, which was used to capture sulfur during the combustion process.

XRD characterization was performed on the 1.4-1.8 SG coal sources and the corresponding calcined samples. As shown in Figure 1, the dominant minerals in the West Kentucky No. 13 and Illinois No. 6 coal samples were illite, kaolinite, quartz, pyrite and anatase. Fire Clay coals contained a minor amount of pyrite while the kaolinite and quartz contents were higher than the other two sources. This agrees with the fact that volcanic ash contributed significantly to the inorganic matter in the Fire Clay coal. When the coals were calcined at high temperatures, mineralogical changes occurred. For all three coals, XRD peaks corresponding to kaolinite disappeared after calcination at $600^{\circ} \mathrm{C}$ and $900^{\circ} \mathrm{C}$. This can be explained by the dehydroxylation of the kaolinite crystal structures..$^{42,43}$ When the coals were calcined at $900^{\circ} \mathrm{C}$, the crystal structure of illite was partially destroyed relative to the samples calcined at $600^{\circ} \mathrm{C}$, which can be discerned from the differences in the diffraction peak intensity (e.g., IL6 in Figure 1). Pyrite in the coals were completely transformed into hematite after calcination at $600^{\circ} \mathrm{C}$ or higher.

The major minerals in the FBC ash samples were quartz, illite, hematite and some Cabearing minerals such as lime, anhydrite and calcite (Figure 2). The significant amount of anhydrite was formed by the reaction between lime and sulfur in the FBC systems. The mineralogy of FBC ash materials are similar to that of the calcined samples, which indicates a similar oxidation/carbon removal process. The mineralogy of the calcined coals and FBC ash are distinct from the conventional power plant ash materials which are characterized by relatively scattered XRD patterns indicative of a composition of mostly amorphous glass structure with some crystalline quartz and new mineral phases such as mullite and magnetite. ${ }^{35}$ Pulverized-coal fired boilers typically operate at temperatures between $1480-1590^{\circ} \mathrm{C}$, which promote the transition of the mineral matter from a crystalline structure to mostly a glassy amorphous material which are 
difficult to leach. ${ }^{34,44}$ As such, the XRD findings support the hypothesis that REEs are likely more easily recovered from the ash materials generated from coal burned at relatively low temperatures such as those used in the FBC units. 
Table 1. Ash (\%) and REE (ppm, dry ash basis) contents of the coals and fly ash samples as well as the heavy to light REE ratios (H/L)

\begin{tabular}{|c|c|c|c|c|c|c|c|c|c|c|c|c|c|c|c|c|c|c|c|c|c|c|}
\hline Sample & Density & Ash & TREE & HREE & LREE & $\mathrm{H} / \mathrm{L}$ & $\mathrm{Sc}$ & $\mathrm{Y}$ & $\mathrm{La}$ & $\mathrm{Ce}$ & $\operatorname{Pr}$ & $\mathrm{Nd}$ & $\mathrm{Sm}$ & $\mathrm{Eu}$ & $\mathrm{Gd}$ & $\mathrm{Tb}$ & Dy & $\mathrm{Ho}$ & $\mathrm{Er}$ & $\mathrm{Tm}$ & $\mathrm{Yb}$ & $\overline{\mathrm{Lu}}$ \\
\hline \multirow{2}{*}{ WK13 } & 1.4 SG float & 6.71 & 490 & 165 & 325 & 0.51 & 49.4 & 83.4 & 51.1 & 110.2 & 18.9 & 70.3 & 25.0 & 4.9 & 19.8 & 7.1 & 17.1 & 0.0 & 10.3 & 3.1 & 12.4 & 6.4 \\
\hline & $1.4-1.8 \mathrm{SG}$ & 24.9 & 552 & 129 & 423 & 0.31 & 41.9 & 56.1 & 63.0 & 161.0 & 25.8 & 98.9 & 32.3 & 6.3 & 22.4 & 6.0 & 13.4 & 0.0 & 7.9 & 1.6 & 9.9 & 5.3 \\
\hline \multirow[b]{2}{*}{ IL6 } & 1.4 SG float & 7.13 & 393 & 103 & 290 & 0.36 & 29.8 & 50.1 & 52.5 & 114.3 & 18.3 & 57.6 & 17.5 & 2.9 & 13.8 & 3.4 & 14.6 & 0.2 & 5.9 & 1.9 & 7.1 & 3.6 \\
\hline & $1.4-1.8 \mathrm{SG}$ & 17.83 & 342 & 76 & 266 & 0.28 & 18.1 & 28.3 & 48.2 & 109.4 & 18.9 & 52.6 & 18.9 & 2.0 & 10.7 & 3.0 & 16.0 & 0.0 & 3.5 & 0.8 & 5.8 & 5.3 \\
\hline \multirow{2}{*}{$\mathrm{FC}$} & 1.4 SG float & 6.36 & 2014 & 497 & 1517 & 0.33 & 57.9 & 294.3 & 288.9 & 730.0 & 74.6 & 303.8 & 62.1 & 6.3 & 53.4 & 3.4 & 65.8 & 11.7 & 22.0 & 8.7 & 26.3 & 4.5 \\
\hline & $1.4-1.8 \mathrm{SG}$ & 30.62 & 1026 & 188 & 838 & 0.22 & 38.0 & 99.6 & 163.0 & 396.9 & 41.5 & 165.5 & 33.3 & 4.2 & 27.3 & 0.9 & 26.3 & 5.5 & 10.9 & 2.6 & 9.7 & 1.3 \\
\hline \multirow{2}{*}{$\mathrm{FBC} 1$} & Fly ash & 97.28 & 232 & 179 & 53 & 0.30 & 11.0 & 19.5 & 29.7 & 73.0 & 14.5 & 47.3 & 3.1 & 1.4 & 18.6 & 2.7 & 3.5 & 0.8 & 3.7 & 1.1 & 1.1 & 0.8 \\
\hline & Bottom ash & 98.34 & 96 & 71 & 26 & 0.36 & 5.6 & 11.6 & 11.8 & 24.7 & 6.9 & 20.1 & 1.4 & 0.7 & 5.7 & 1.1 & 2.1 & 0.5 & 2.4 & 0.3 & 1.0 & 0.3 \\
\hline \multirow{2}{*}{ FBC2 } & Fly ash & 96.34 & 289 & 232 & 57 & 0.25 & 16.3 & 21.3 & 43.3 & 101.9 & 18.3 & 42.9 & 9.3 & 1.2 & 15.7 & 2.8 & 3.6 & 1.2 & 8.3 & 3.2 & 0.0 & 0.0 \\
\hline & Bottom ash & 99.47 & 295 & 240 & 55 & 0.23 & 15.1 & 18.0 & 47.4 & 107.0 & 17.0 & 44.7 & 8.7 & 1.4 & 15.7 & 2.3 & 3.5 & 1.5 & 10.3 & 2.7 & 0.0 & 0.0 \\
\hline
\end{tabular}



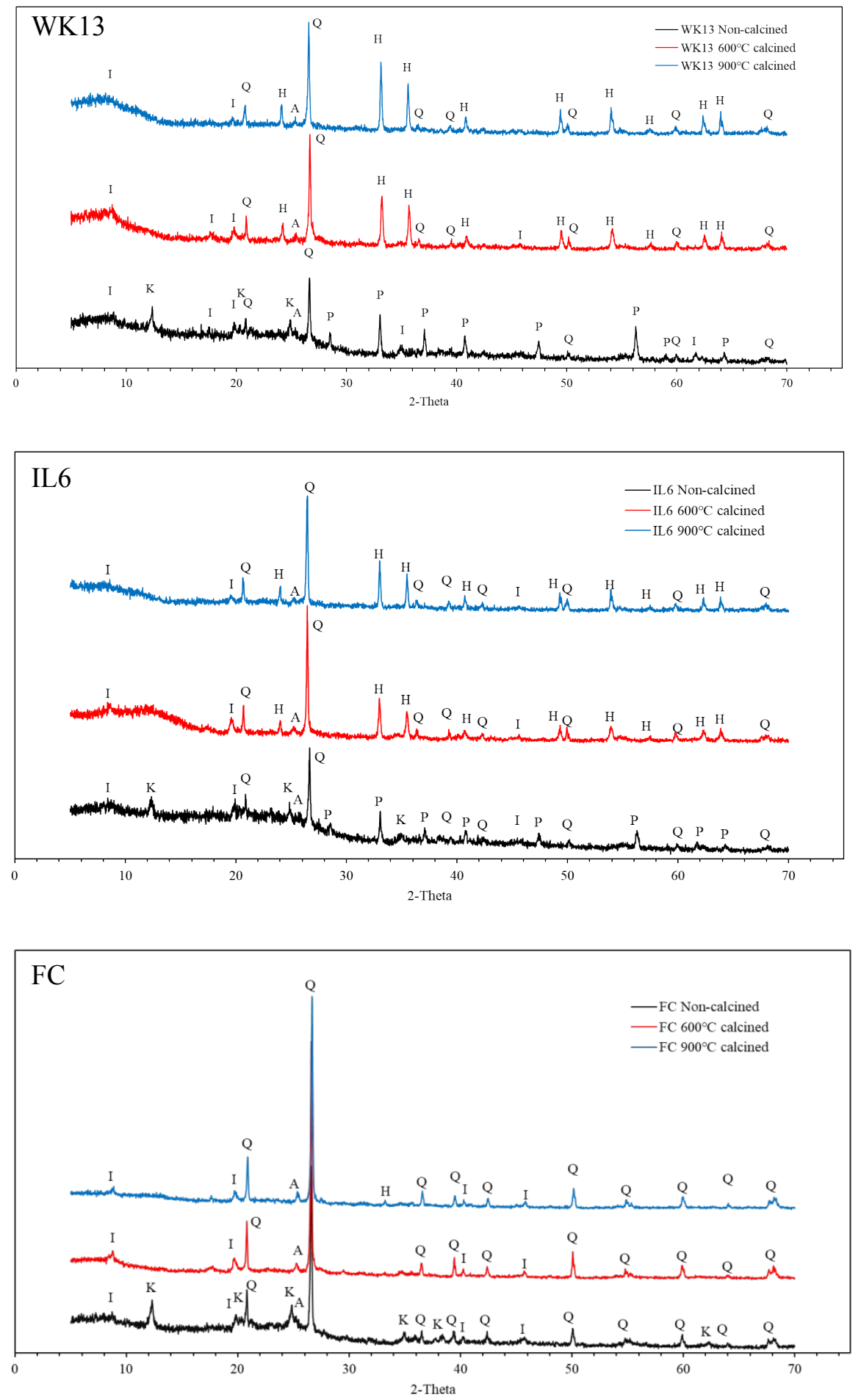

Figure 1. XRD patterns of the 1.4-1.8 SG samples of West Kentucky No. 13 (WK13), Illinois No. 6 (IL6), and Fire Clay (FC) with and without calcination treatment: A-anatase $\left(\mathrm{Ti}_{2} \mathrm{O}\right), \mathrm{H}$-hematite $\left(\mathrm{Fe}_{2} \mathrm{O}_{3}\right)$, I-illite $\left(\left(\mathrm{K}, \mathrm{H}_{3} \mathrm{O}\right)(\mathrm{Al}, \mathrm{Mg}, \mathrm{Fe})_{2}(\mathrm{Si}, \mathrm{Al})_{4} \mathrm{O}_{10}\right), \mathrm{K}$-kaolinite $\left(\mathrm{Al}_{2} \mathrm{Si}_{2} \mathrm{O}_{5}(\mathrm{OH})_{4}\right)$, P-pyrite $\left(\mathrm{FeS}_{2}\right)$, and Q-quartz $\left(\mathrm{SiO}_{2}\right)$. 
Figure 2. XRD patterns of the FBC ash samples: A-anhydrite $\left(\mathrm{CaSO}_{4}\right), \mathrm{C}$-calcite $\left(\mathrm{CaCO}_{3}\right), \mathrm{H}-$ hematite $\left(\mathrm{Fe}_{2} \mathrm{O}_{3}\right)$, I-illite $\left(\left(\mathrm{K}, \mathrm{H}_{3} \mathrm{O}\right)(\mathrm{Al}, \mathrm{Mg}, \mathrm{Fe})_{2}(\mathrm{Si}, \mathrm{Al})_{4} \mathrm{O}_{10}\right)$, L-lime $(\mathrm{CaO})$, and Q-quartz $\left(\mathrm{SiO}_{2}\right)$.

3.2 Calcined Sample Leaching Results. Acid leaching tests were performed on both the original and calcined coal samples to compare the REE leaching characteristics. As shown in Figure 3 , REE recovery was significantly improved by calcination at high temperatures. By calcining at $600^{\circ} \mathrm{C}$ for 2 hours, about $80 \%$ of REEs were leached from the West Kentucky No. 13 and Fire Clay coal sources, which is slightly higher than the values obtained from the Illinois No. 6 coal source (i.e., about $75 \%$ ). However, without any calcination, the REE recovery was relatively low, e.g., only $25 \%$ of REEs were leached from the original West Kentucky No. 131.4 SG float sample. As shown in Figure 4, HREE recovery from the 1.4 SG float samples was also increased significantly by calcining at $600^{\circ} \mathrm{C}$ for 2 hours, which is similar to the total REEs. However, for the 1.4-1.8 SG samples, the increase in HREE recovery is $30-40 \%$ and lower than the total REEs (see Figure 4 and 3).

REEs in low-ash coals can be classified into organic (in forms of organic compounds and/or ionic species in the carbon matrix) and inorganic (ash-forming mineral matter dispersed within the organic matrix) associations. ${ }^{18,19}$ There are two factors that may contribute to the enhanced recovery after calcination: (1) the organically and inorganically associated REEs were liberated after calcination, which might be more leachable (e.g., REEs on the surfaces and entrapped within the inner layer of micro-dispersed clays; and (2) high temperature calcination transformed the REEs into more leachable forms such as rare earth oxides. After calcination at $600^{\circ} \mathrm{C}$ or higher for 2 hours, the organic matter was completely removed from all the coals as indicated by proximate analysis data. The findings of a previous study reported by Mardon and Hower ${ }^{45}$ showed that REEs are relatively non-volatile when coals are burned in boilers $\left(>1000^{\circ} \mathrm{C}\right)$. As such, all the organically associated REEs stayed in the coal ashes, most likely in the form of an oxide. However, in high rank coals, the organically associated REEs represent a small fraction of the total REEs, i.e., less than $10 \%$ for LREEs ${ }^{46}$, and thus the enhanced recovery was more likely due to the mineralogy changes caused by calcination. It has been reported that a portion of the REEs are associated with clays in coal. ${ }^{4,19}$ Calcination of clays, especially kaolinite, causes dehydration which significantly increases their surface area. ${ }^{43,47}$ This effect may provide another explanation for the enhanced recovery and agrees with the XRD characterization findings (see Figure 1). 
As shown in Figure 3, REE recovery was significantly decreased when the coals were calcined at $900^{\circ} \mathrm{C}$ relative to $750^{\circ} \mathrm{C}$ and $600^{\circ} \mathrm{C}$. This finding may be due to the pozzolanic nature of clays after calcination using temperatures around $900^{\circ} \mathrm{C}$ which reduce the surface area and encapsulate the associated REEs. In this case, strong acids would be needed to dissolve the clays to recover the encapsulated REEs. Much higher temperatures $\left(>1200^{\circ} \mathrm{C}\right)$ are utilized in pulverized coal fired combustion (PCC) boilers. As such, the calcination test results on the coal samples at $900^{\circ} \mathrm{C}$ highlighted the difficulty of REE recovery from the conventional PCC fly ash and bottom ash sources. FBC units utilize coal significantly lower temperatures, typically $750-900^{\circ} \mathrm{C}$, with an Few units operating at or slightly below $700^{\circ} \mathrm{C} .{ }^{39,40}$ Under these conditions, fusion of associated coal minerals in the FBC unit is low, which benefits the REE recovery from the corresponding fly ash and bed ash materials.
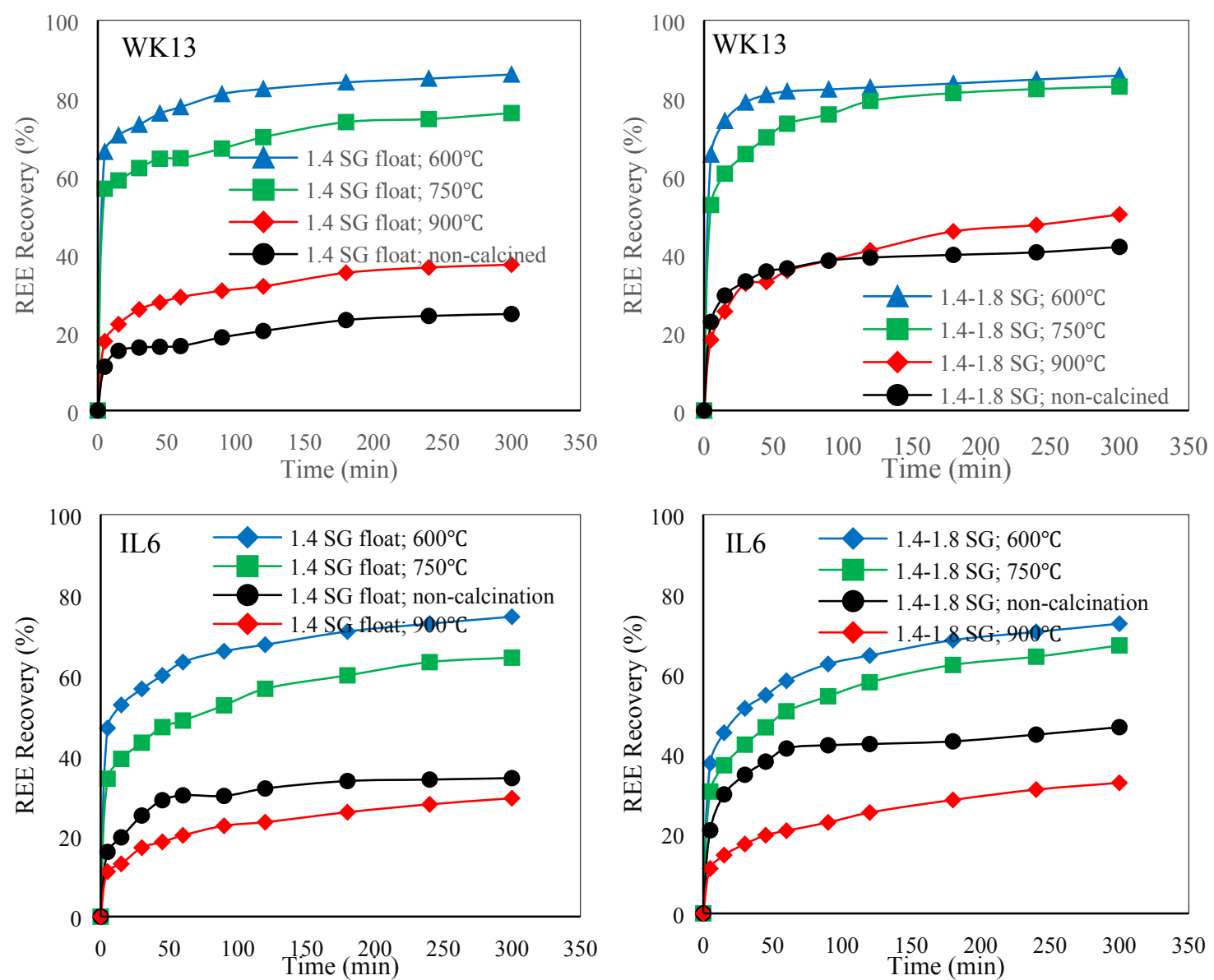

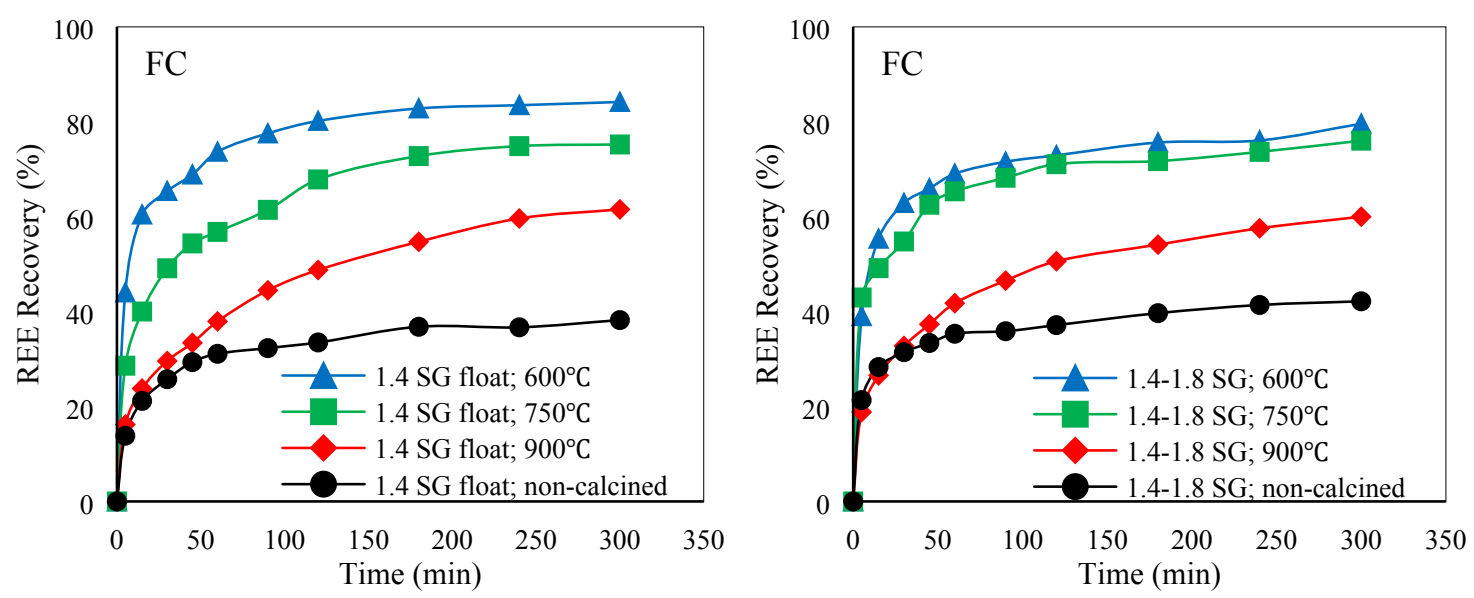

Figure 3. Effects of calcination temperature on acid leaching recovery of REEs from the West Kentucky No. 13 (WK13), Fire Clay (FC), and Illinois No. 6 (IL6) coals.
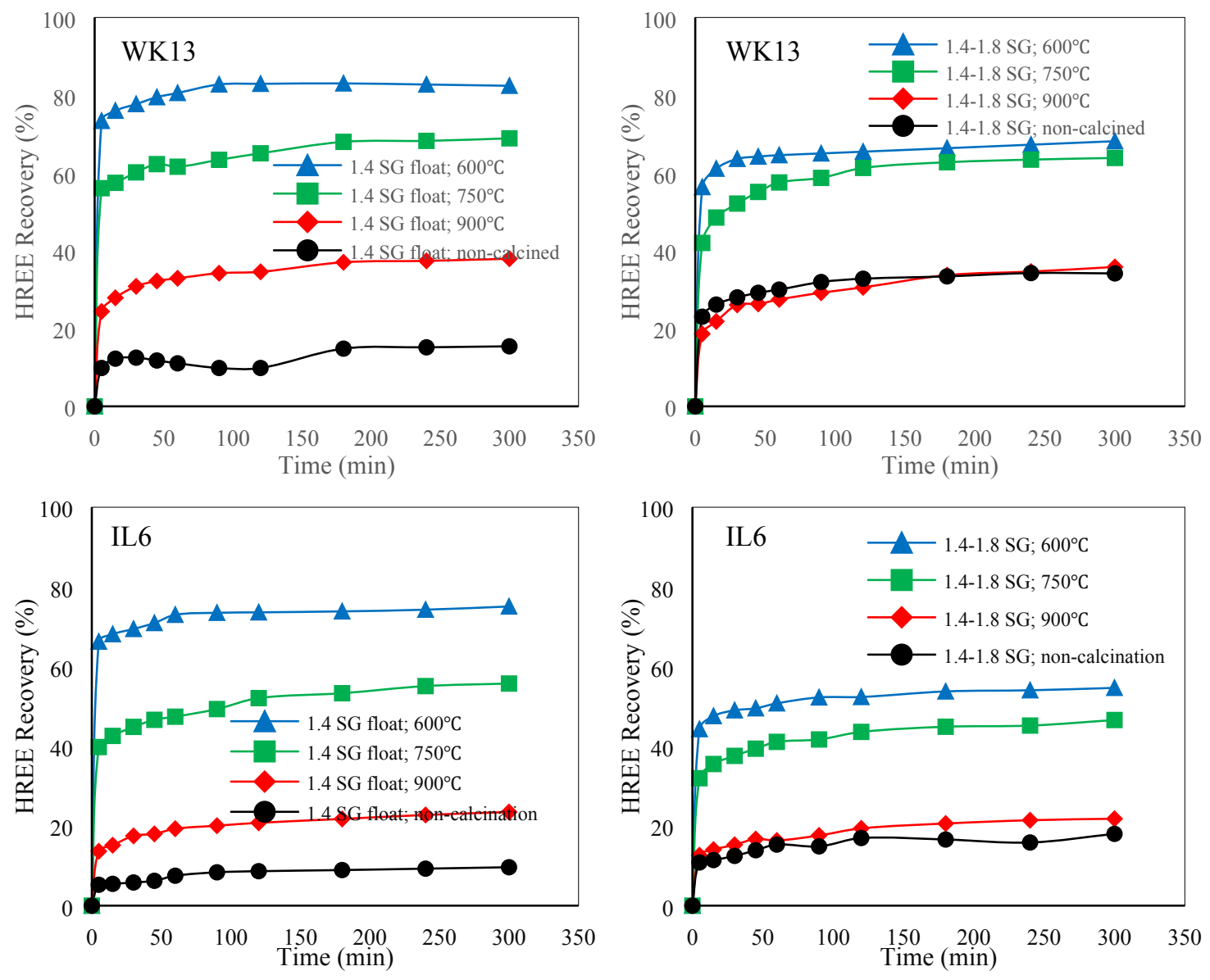

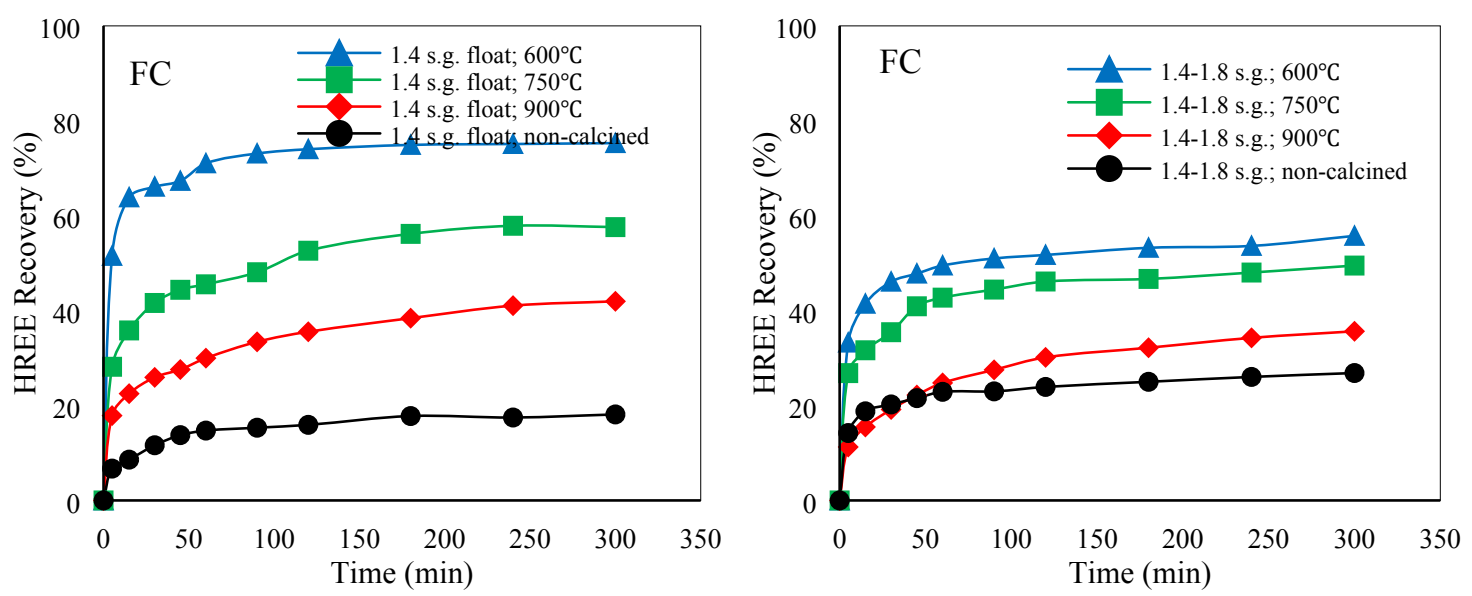

Figure 4. Effects of calcination temperature on acid leaching recovery of HREEs from the West Kentucky No. 13 (WK13), Fire Clay (FC), and Illinois No. 6 (IL6) coals.

The acid leaching kinetics of REEs from the calcined samples were characterized by a quick release within the first five minutes of the leaching process (see Figure 3 and 4). For example, about $70 \%$ of the REEs were leached from the West Kentucky No. 13 samples in the first 5 min. Solvent extraction is normally used to concentrate REEs from the leachate. As reported by Honaker et al. ${ }^{25}, \mathrm{Fe}$ is the most difficult contaminant in the leachate due to the relatively high complexing ability of $\mathrm{Fe}^{3+}$ with the extractant, D2EPHA (di-(2-ethylhexyl) phosphoric acid). As shown in Figure 5, although the overall Fe recovery from the calcined samples increased after calcination, the recovery was relatively low at the beginning of the leaching process. Within the first $15 \mathrm{~min}$, Fe recovery from the calcined samples was lower than the non-calcined samples. The differential leaching kinetics between the REEs and Fe benefit the technical and economic feasibility of producing a high grade concentrate using solvent extraction. An additional benefit of the calcination process is that a portion of the Fe is converted to hematite which has lower solubility ${ }^{48}$ (see Figure 1).
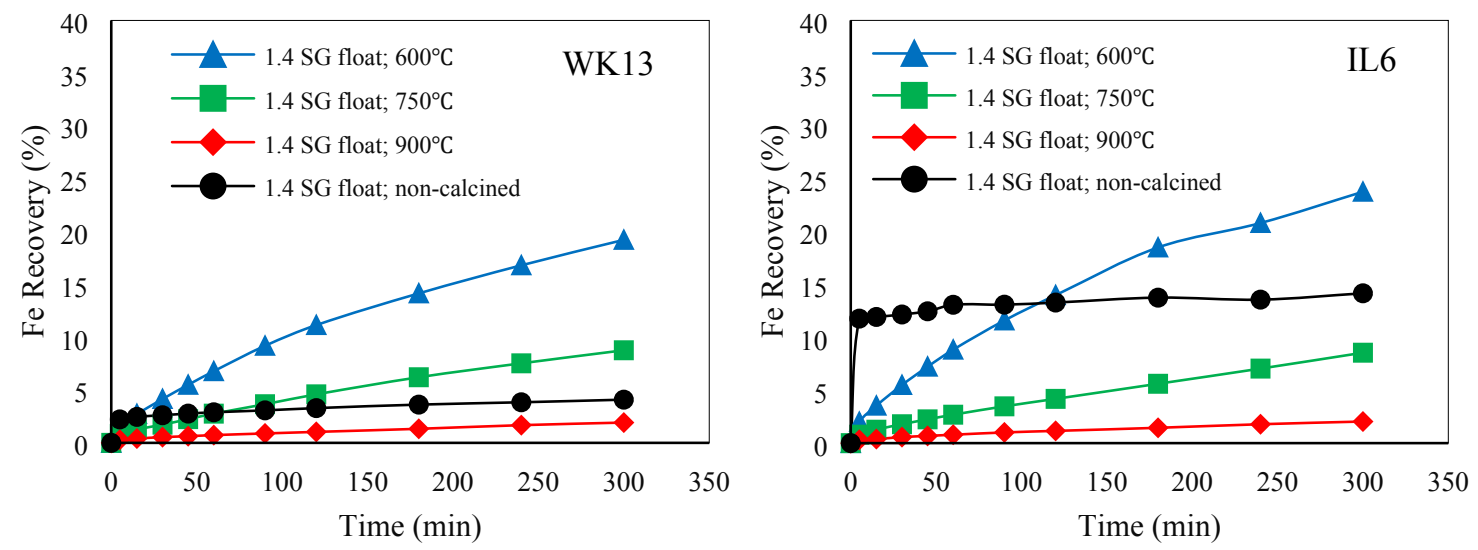

Figure 5. Effects of calcination temperature on acid leaching recovery of Fe from the West Kentucky No. 13 (WK13) and Illinois No. 6 (IL6) coals.

The effects of pretreatment time on REE leaching recovery from the coal sources are critical since the residence time in a FBC unit is limited, varying from several seconds to several 
minutes $^{49}$. As shown in Figure 6(a), the majority of the organic matter was combusted after 10 min of calcination at $600^{\circ} \mathrm{C}$ (ash contents $>75 \%$ ). When the calcination was increased to $30 \mathrm{~min}$, combustion of the organic matter was nearly complete. As such, the effects of organic matter, such as physical encapsulation of rare earth minerals, on REE leaching are negligible. When the calcined samples were leached at $75^{\circ} \mathrm{C}$ using $1.2 \mathrm{M} \mathrm{HCl}$, nearly equal leaching recovery values and kinetics were observed between the coal samples calcined at 10, 60 and $120 \mathrm{~min}$ (see Figure 6(b)-(d)). This indicates that a minimum of 10 minutes of calcination or exposure to similar conditions in a FBC unit is needed to realize the desired leaching characteristics.
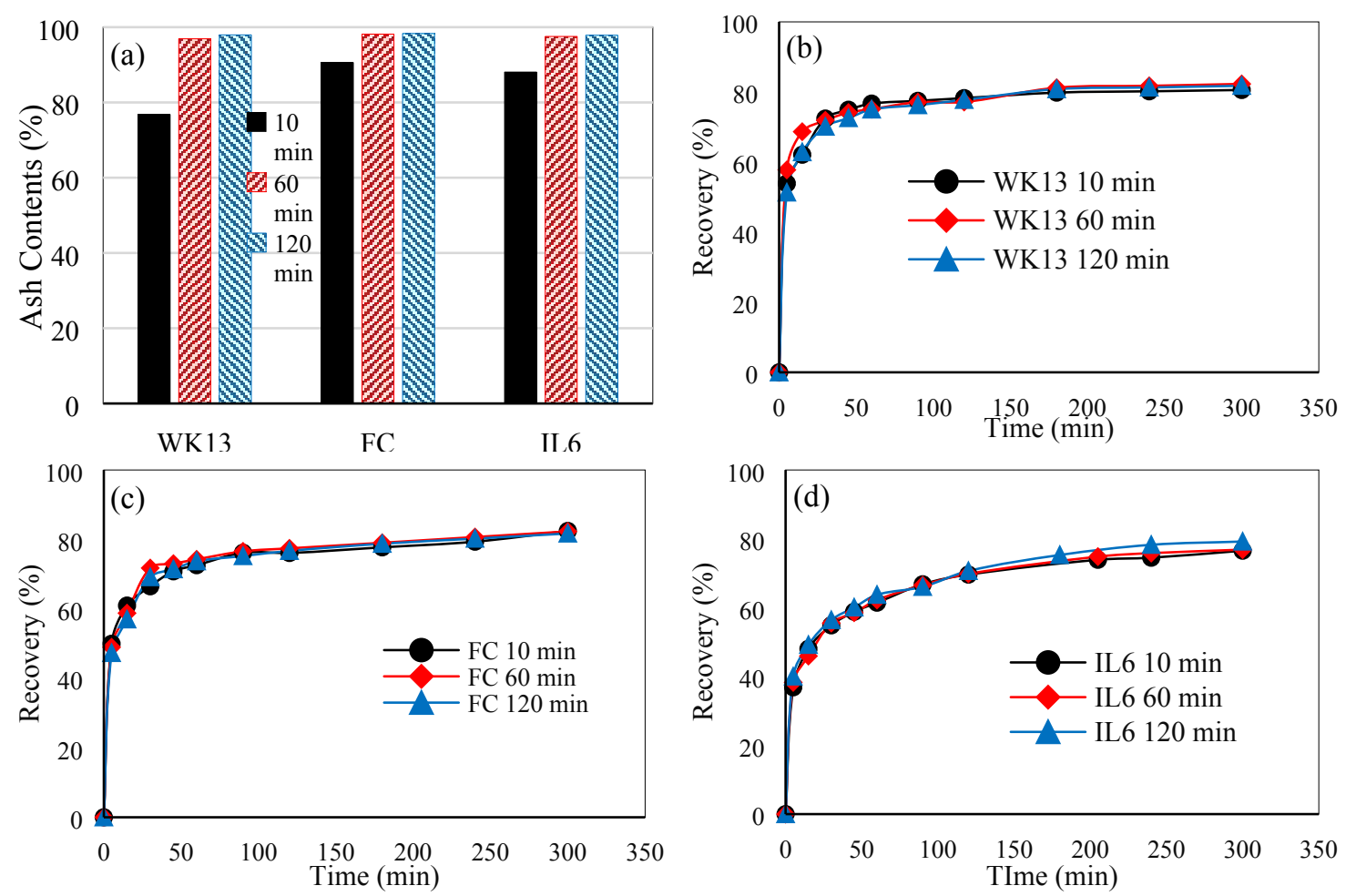

Figure 6. Effects of calcination time at $600^{\circ} \mathrm{C}$ on (a) the ash contents and (b-d) REE leaching recovery of the 1.4 x 1.8 SG fraction of each coal source.

3.3 FBC Ash Sample Leaching Results. The results obtained from the acid leaching tests performed on the FBC ash samples are shown in Figure 7. Similar to the calcined coal samples, the leaching kinetics of the ash samples were also found to be characterized by a quick release within the first five minutes. A maximum recovery value of around $80 \%$ occurred with the FBC1 bottom ash while relatively lower percentages (about 60\%) were recovered from the other ash samples. Leaching results of the calcined coal samples indicated that the pretreatment temperature is critical for REE recovery and excessive calcination $\left(\geq 750^{\circ} \mathrm{C}\right)$ impairs acid leaching performance (see Figure 3). The maximum REE recovery occurred with the $\mathrm{FBC1}$ bed ash material which was exposed to a lower temperature $\left(790^{\circ} \mathrm{C}\right)$ relative to the $\mathrm{FBC} 2$ ash materials $\left(870^{\circ} \mathrm{C}\right)$. This temperature is near the complete decomposition temperature for clay materials. ${ }^{47}$

The FBC2 unit receives feed from the Illinois No. 6 coal seam and tests conducted on the 1.4 SG float and 1.4 x 1.8 SG fractions of a sample collected from the same seam revealed that a calcination temperature of $900^{\circ} \mathrm{C}$ reduces REE recovery to values approaching $30 \%$ (see Figure 3). The leach recovery values achieved for the FBC2 ash materials were around 60\% (see Figure 7) 
which indicates that the temperatures and associated conditions in the unit did not result in the transformation of the mineral forms into a state having a significantly reduced solubility. Based on these findings, a FBC unit used to produce electricity and assist in the recovery of critical elements from coal-based sources should be operated at a temperature that is no more than $750^{\circ} \mathrm{C}$.

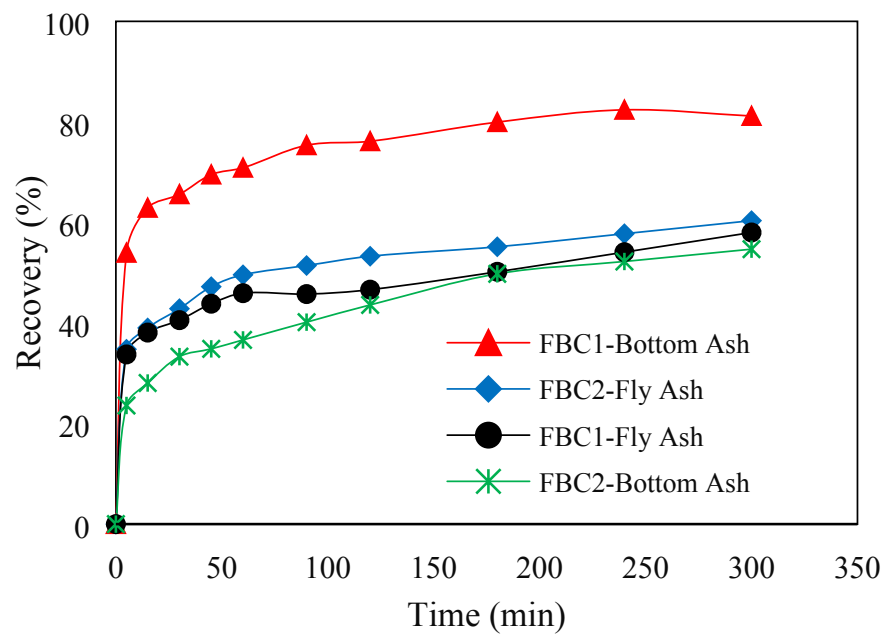

Figure 7. Leaching characteristics of REEs from the fly ash and bottom ash samples.

3.4 A Conceptual Flowsheet for REE Recovery from Coal. Based on the above findings, a process flowsheet was developed that utilizes a FBC system to produce power from the combustion of coal and assists in feed preparation of the ash materials for the recovery of the associated REEs. As shown in Figure 8, the system contains a FBC unit, acid leaching system, solvent extraction units, selective precipitation tanks and a roaster to produce the rare earth oxide concentrate. Preferred modifications to a typical FBC operation is the use of a combustion temperature of around $750^{\circ} \mathrm{C}$ and the elimination of the lime addition into the combustion chamber. The off-gas produced from the FBC unit could be processed to produce the sulfuric acid that is needed for the leaching process. As a result, the REE content of the ash byproducts should be significantly higher and acid consumption lower due to the removal of an acid consuming material.

The hydrometallurgical processes and circuit have been proven technically feasible for coal-related sources based on data obtained from laboratory and pilot-plant testing. ${ }^{28,} 30$ Both the energy and REEs associated with the coal can be recovered using the proposed method. The REEs recovered from the circuit are produced in forms of more than $99 \%$ pure mixed oxides from this circuit.

A preliminary estimate of the values associated with the energy and REE recovered from 1 tonne of a coal using the flowsheet in Figure 8 is shown in Table 2. A typical coal feed was considered which contained 4,450 kcal $/ \mathrm{kg}(8,000 \mathrm{btu} / \mathrm{lb})$, an ash content of around $30 \%$ and 700 ppm of REEs on a dry ash basis. Power generation from the coal is the primary economic driver based on current market values for energy and rare earth products. The value of the REEs recovered is estimated to be about $20 \%$ of the total coal value which is $\$ 44 / \mathrm{t}$ of feed coal or $\$ 28.67 / \mathrm{t}$ of ash byproduct. It should be noted that this assessment is based on current market values which could change based on future demands and geopolitical issues. Given the national security issues and concerns regarding manufacturing needs, the production of rare earth elements utilizing the 
proposed approach that involves the use of FBC technologies may be a promising avenue toward providing a dependable REE supply, especially HREEs.

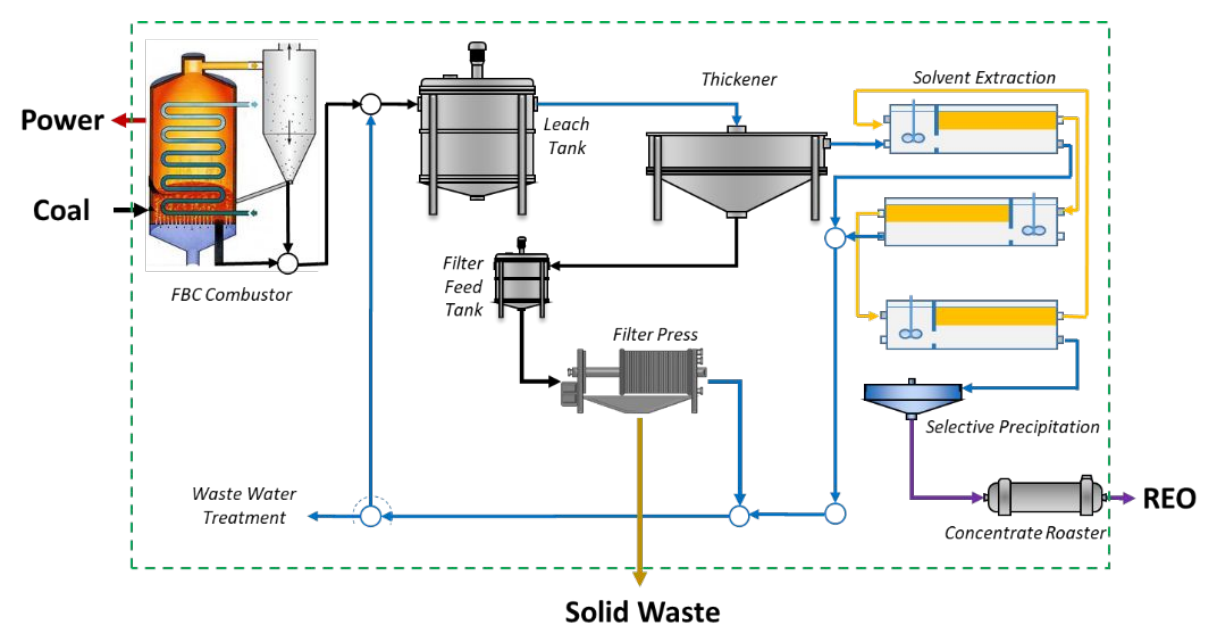

Figure 8. A schematic diagram of REE recovery from coal using the FBC method.

Table 2. A preliminary economic assessment of energy and REO recovery from a coal containing $4,450 \mathrm{kcal} / \mathrm{kg}, 30 \%$ ash and $700 \mathrm{ppm}$ of REEs on an ash basis.

\begin{tabular}{ccc}
\hline Value & Energy $/$ ton $^{1}$ & REO/ton \\
\hline Energy & $4,450 \times 10^{3} \mathrm{kcal}$ & $\mathrm{NA}$ \\
REOs & $\mathrm{NA}$ & $0.17 \mathrm{~kg}$ \\
Total Value & $\$ 35 /$ feed ton & $\$ 9 /$ feed ton \\
\hline
\end{tabular}

Note: 1 . Assuming the coal market value is $\$ 7.93 /$ million kcal; 2 . Assuming the REE recovery and the price of REO to be $70 \%$ and $\$ 50 / \mathrm{kg}$ (referred to the price listed on https://mineralprices.com), respectively, and a coefficient of 1.17 was used to transform the weight of REEs to REO.

\section{Conclusions}

REE leaching recovery characteristics of the original and calcined coal samples collected from three bituminous coal seams (West Kentucky No. 13, Fire Clay, and Illinois No. 6) was investigated in addition to FBC fly ash and bed ash samples from two operating power plants. The focus of the study was the 1.4 SG and 1.4 x 1.8 SG fractions of each pre-combustion coal source because 1) both fractions represent the majority of the fuel feedstock used for electric power generation, and 2) the associated mineral matter is enriched with REEs, especially HREEs. REE recovery values were significantly improved by calcination prior to leaching using temperatures of $600-750^{\circ} \mathrm{C}$ for 2 hours. The REE recovery values decreased significantly when the temperature was elevated to $900^{\circ} \mathrm{C}$. The calcination benefits on REE leaching recovery and kinetics were realized under a residence time as low as 10 min when treating the $1.4 \times 1.8 \mathrm{SG}$ fractions of all three bituminous coal sources. The REE leaching kinetics were characterized by a quick release of REEs within the first five minutes during which recovery values exceeding $60 \%$ were achieved. The FBC ash samples were found to have similar leaching characteristics. However, REE recovery values obtained from treating the FBC byproducts were somewhat lower relative to the calcined samples due to the higher combustion temperatures $\left(790^{\circ} \mathrm{C}\right.$ and $\left.870^{\circ} \mathrm{C}\right)$, especially for the unit with the highest operating temperature. XRD characterization showed that both the calcined coals and the FBC ash samples had similar mineralogical characteristics which are different from the coal ash byproducts produced from pulverized-coal (PCC) fired boilers. PCC units use combustion temperatures exceeding $1200^{\circ} \mathrm{C}$. The relatively high crystallinity of the calcined coal sources and 
FBC byproducts enhances REE extraction as evidenced by high recovery values and lower residence time requirements as compared to the non-calcined bituminous coal sources used in this study and PCC ash byproducts as reported from previous investigations. Based on these findings, a conceptual flowsheet was developed that combines power production and the favorable combustion environment of a FBC to provide an enhanced feedstock for REE recovery and concentration using downstream hydrometallurgical processes.

\section{Author Information \\ Corresponding author: rick.honaker@uky.edu (R.Q. Honaker) \\ Notes: The authors declare no competing financial interest.}

\section{Acknowledgement}

This material is based upon work supported by the Department of Energy under Award Number DE-FE0029900. Disclaimer: This report was prepared as an account of work sponsored by an agency of the United States Government. Neither the United States Government nor any agency thereof, nor any of their employees, makes any warranty, express or implied, or assumes any legal liability or responsibility for the accuracy, completeness, or usefulness of any information, apparatus, product, or process disclosed, or represents that its use would not infringe privately owned rights. Reference herein to any specific commercial product, process, or service by trade name, trademark, manufacturer, or otherwise does not necessarily constitute or imply its endorsement, recommendation, or favoring by the United States Government or any agency thereof. The views and opinions of authors expressed herein do not necessarily state or reflect those of the United States Government or any agency thereof.

\section{References}

(1) Alonso, E.; Sherman, A. M.; Wallington, T. J.; Everson, M. P.; Field, F. R.; Roth, R.; Kirchain, R. E. Evaluating rare earth element availability: A case with revolutionary demand from clean technologies. Envir. Sci. Tech. 2012, 46, 3406-3414.

(2) Klossek, P.; Kullik, J.; van den Boogaart, K. G. A systemic approach to the problems of the rare earth market. Resour. Policy 2016, 50, 131-140.

(3) Zhou, B.; Li, Z.; Chen, C. Global potential of rare earth resources and rare earth demand from clean technologies. Mineral 2017, 7(11), 203.

(4) King, J. F.; Taggart, R. K.; Smith, R. C.; Hower, J. C.; Hsu-Kim, H. Aqueous acid and alkaline extraction of rare earth elements from coal combustion ash. Int. J. Coal Geol. 2018, 195, 75-83.

(5) Honaker, R.; Hower, J.; Eble, C.; Weisenfluh, G.; Groppo, J.; Rezaee, M.; Bhagavatula, A.; Luttrell, G. H.; Bratton, R. C.; Kiser, M.; Yoon, R.H. Laboratory and bench-scale testing for rare earth elements. 2014.

(6) Stewart, B. W.; Capo, R. C.; Hedin, B. C.; Hedin, R. S. Rare earth element resources in coal mine drainage and treatment precipitates in the Appalachian Basin, USA. Int. J. Coal Geol. 2017, 169, 28-39. 
(7) Zhang, W.; Rezaee, M.; Bhagavatula, A.; Li, Y.; Groppo, J.; Honaker, R. A review of the occurrence and promising recovery methods of rare earth elements from coal and coal by-products. Int. J. Coal Prep. Util. 2015, 35(6), 295-330.

(8) Zhang, W.; Honaker, R. Q. Rare earth elements recovery using staged precipitation from a leachate generated from coarse coal refuse. Int. J. Coal Geol. 2018a, 195, 189-199.

(9) Zhang, W.; Honaker, R.; Groppo, J. Concentration of rare earth minerals from coal by froth flotation. Miner. Metall. Proc. 2017, 34(3), 1-7.

(10) Hower, J. C.; Eble, C. F.; Dai, S.; Belkin, H. E. Distribution of rare earth elements in eastern Kentucky coals: indicators of multiple modes of enrichment?. Int. J. Coal Geol. 2016, 160, 73-81.

(11) Seredin, V. V.; Dai, S. Coal deposits as potential alternative sources for lanthanides and yttrium. Int. J. Coal Geol. 2012, 94, 67-93.

(12) Dai, S.; Wang, X.; Seredin, V. V.; Hower, J. C.; Ward, C. R.; O'Keefe, J. M.; Huang, W.; Li, T.; Li, X.; Liu, H.; Xue, W.; Zhao, L. Petrology, mineralogy, and geochemistry of the Ge-rich coal from the Wulantuga Ge ore deposit, Inner Mongolia, China: new data and genetic implications. Int. J. Coal Geol. 2012, 90, 7299.

(13) Eskenazy, G. M. Trace elements geochemistry of the Dobrudza coal basin, Bulgaria. Int. J. Coal Geol. 2009, 78(3), 192-200.

(14) Hower, J. C.; Ruppert, L. F.; Eble, C. F. Lanthanide, yttrium, and zirconium anomalies in the Fire Clay coal bed, Eastern Kentucky. Int. J. Coal Geol. 1999, 39(1-3), 141-153.

(15) Hower, J. C.; Berti, D.; Hochella Jr, M. F.; Mardon, S. M. Rare earth minerals in a "no tonstein" section of the Dean (Fire Clay) coal, Knox County, Kentucky. Int. J. Coal Geol. 2018, 193, 73-86.

(16) Birk, D.; White, J. C. Rare earth elements in bituminous coals and underclays of the Sydney Basin, Nova Scotia: Element sites, distribution, mineralogy. Int. J. Coal Geol. 1991, 19(1-4), 219-251.

(17) Seredin, V. V. Rare earth element-bearing coals from the Russian Far East deposits. Int. J. Coal Geol. 1996, 30(1-2), 101-129.

(18) Wang, W.; Qin, Y.; Sang, S.; Zhu, Y.; Wang, C.; Weiss, D. J. Geochemistry of rare earth elements in a marine influenced coal and its organic solvent extracts from the Antaibao mining district, Shanxi, China. Int. J. Coal Geol. 2008, 76(4), 309-317.

(19) Zhang, W.; Yang, X.; Honaker, R. Q. Association characteristic study and preliminary recovery investigation of rare earth elements from Fire Clay seam coal middlings. Fuel 2018b, 215, 551-560.

(20) Crowley, S. S.; Stanton, R. W.; Ryer, T. A. The effects of volcanic ash on the maceral and chemical composition of the C coal bed, Emery Coal Field, Utah. Org. Geochem. 1989, 14(3), 315-331.

(21) Dai, S.; Liu, J.; Ward, C. R.; Hower, J. C.; French, D.; Jia, S.; Hood, M. M.; Garrison, T. M. Mineralogical and geochemical compositions of Late Permian coals and host rocks from the Guxu Coalfield, Sichuan Province, China, with emphasis on enrichment of rare metals. Int. J. Coal Geol. 2016, 166, 71-95.

(22) Eskenazy, G. M. Rare earth elements in a sampled coal from the Pirin deposit, Bulgaria. Int. J. Coal Geol. 1987, 7(3), 301-314.

(23) Stern, J. C.; Sonke, J. E.; Salters, V. J. A capillary electrophoresis-ICP-MS study of rare earth element complexation by humic acids. Chem. Geol. 2007, 246(3-4), 170-180. 
(24) Sonke, J. E.; Salters, V. J. Lanthanide-humic substances complexation. I. Experimental evidence for a lanthanide contraction effect. Geochim. Cosmochim. Ac. 2006, 70(6), 1495-1506.

(25) Honaker, R.; Yang, X.; Chandra, A.; Zhang, W.; Werner, J. Hydrometallurgical Extraction of Rare Earth Elements from Coal. In Extraction 2018 (pp. 2309-2322). Springer, Cham.

(26) Honaker, R. Q.; Groppo, J.; Yoon, R. H.; Luttrell, G. H.; Noble, A.; Herbst, J. Process evaluation and flowsheet development for the recovery of rare earth elements from coal and associated byproducts. Miner. Metall. Proc. 2017, 34(3).

(27) Laudal, D. A.; Benson, S. A.; Addleman, R. S.; Palo, D. Leaching behavior of rare earth elements in fort union lignite coals of North America. Int. J. Coal Geol. 2018, 191, 112-124.

(28) Yang, X.; Werner, J.; Honaker, R. Leaching of rare earth from an Illinois Basin coal source. J. Rare Earth 2018. https://doi.org/10.1016/j.jre.2018.07.003.

(29) Luttrell, G. H.; Kiser, M. J.; Yoon, R. H.; Bhagavatula, A.; Rezaee M.; Honaker, R. Q. Concentrations of Rare Earth Elements Generated by U.S. Coal Preparation Plants. Proceedings of the Coal Preparation Conference, Louisville, Kentucky, 2016, pp. 35 - 41.

(30) Huang, Q.; Noble, A.; Herbst, J.; Honaker, R. Liberation and release of rare earth minerals from Middle Kittanning, Fire Clay, and West Kentucky No. 13 coal sources. Powder Technol. 2018, 332, 242-252.

(31) Lin, R.; Stuckman, M.; Howard, B. H.; Bank, T. L.; Roth, E. A.; Macala, M. K.; Lopano C.; Soong Y., Granite, E. J. Application of sequential extraction and hydrothermal treatment for characterization and enrichment of rare earth elements from coal fly ash. Fuel 2018, 232, 124-133.

(32) Taggart, R. K.; Hower, J. C.; Hsu-Kim, H. Effects of roasting additives and leaching parameters on the extraction of rare earth elements from coal fly ash. Int. J. Coal Geol. 2018, 196, 106-114.

(33) Blissett, R. S.; Rowson, N. A. A review of the multi-component utilisation of coal fly ash. Fuel 2012, $97,1-23$.

(34) Hower, J. C.; Groppo, J. G.; Joshi, P.; Dai, S.; Moecher, D. P.; Johnston, M. N. Location of cerium in coal-combustion fly ashes: implications for recovery of lanthanides. Coal Combustion and Gasification Products 2013, 5(1), 73-78.

(35) Ward, C. R.; French, D. Relation between coal and fly ash mineralogy, based on quantitative X-ray diffraction methods. 2005 World Coal Ash (WOCA), April, 11, 15.

(36) Pan, J.; Zhou, C.; Liu, C.; Tang, M.; Cao, S.; Hu, T.; Ji, W.; Luo, Y.; Wen, M.; Zhang, N. Modes of Occurrence of Rare Earth Elements in Coal Fly Ash: A Case Study. Energ. Fuel 2018, 32(9), 9738-9743.

(37) Wang, Z.; Dai, S.; Zou, J.; French, D.; Graham, I. T. Rare earth elements and yttrium in coal ash from the Luzhou power plant in Sichuan, Southwest China: Concentration, characterization and optimized extraction. Int. J. Coal Geol. 2019, 203, 1-14.

(38) Zhang, W.; Honaker, R. Calcination pretreatment effects on acid leaching characteristics of rare earth elements from middlings and coarse refuse material associated with a bituminous coal source. Fuel 2019, 249, 130-145.

(39) Mastral, A. M.; Callen, M. S.; Garcia, T. Fluidized bed combustion (FBC) of fossil and nonfossil fuels. A comparative study. Energ. Fuel 2000, 14(2), 275-281.

(40) Li, P. W.; Chyang, C. S.; Ni, H. W. An experimental study of the effect of nitrogen origin on the formation and reduction of NOx in fluidized-bed combustion. Energy 2018, 154, 319-327. 
(41) ASTM D6357-11. Test Methods for Determination of Trace Elements in Coal, Coke, \& Combustion Residues from Coal Utilization Processes by Inductively Coupled Plasma Atomic Emission, Inductively Coupled Plasma Mass, \& Graphite Furnace Atomic Absorption Spectrometry

(42) Cao Z.; Cao Y.; Dong H.; Zhang J.; Sun C. Effect of calcination condition on the microstructure and pozzolanic activity of calcined coal gangue. Int. J. Miner. Process. 2016, 146: 23-8.

(43) Yagüe, S.; Sánchez, I.; Vigil de La Villa, R.; García-Giménez, R.; Zapardiel, A.; Frías, M. Coal-mining tailings as a pozzolanic material in cements industry. Mineral 2018; 8(2): 46.

(44) Tillman, D.; Duong, D.; Harding, N. S. Solid fuel blending: principles, practices, and problems. Elsevier, 2012.

(45) Mardon, S. M.; Hower, J. C. Impact of coal properties on coal combustion by-product quality: examples from a Kentucky power plant. Int. J. Coal Geol. 2004, 59(3-4), 153-169.

(46) Finkelman, R. B.; Palmer, C. A.; Wang, P. Quantification of the modes of occurrence of 42 elements in coal. Int. J. Coal Geol. 2018, 185, 138-160.

(47) Li, D.; Song, X.; Gong, C.; Pan, Z. Research on cementitious behavior and mechanism of pozzolanic cement with coal gangue. Cement Concrete Res. 2006, 36(9), 1752-1759.

(48) Rickard, D.; Luther, G. W. Chemistry of iron sulfides. Chem. Rev. 2007, 107(2), 514-562.

(49) Rao, J. S.; Ramani, N. V. S.; Pant, H. J.; Reddy, D. N. Measurement of residence time distributions of coal particles in a Pressurized Fluidized Bed Gasifier (PFBG) using radio tracer technique. Indian J. Sci. Technol. 2012, 5(12), 3746-3752. 